\title{
The effectiveness of long-term aripiprazole injections to a patient with paranoid schizophrenia: a case report
}

\author{
Kilkuletnie, skuteczne leczenie schizofrenii paranoidalnej aripiprazolem \\ podawanym domięśniowo - opis przypadku
}

\begin{abstract}
Anna Maria SzotaABCDEF, https://orcid.org/0000-0002-9184-342X, Aleksander
AraszkiewiczABCDEF, https://orcid.org/0000-0003-4324-4112
\end{abstract}

Department of Psychiatry, Collegium Medicum in Bydgoszcz; Nicolaus Copernicus

University in Torun, Poland

\begin{abstract}
Paranoid schizophrenia is a chronic, psychotic disorder which can be treated with long-acting injectable (LAI) antipsychotic drugs. There are risperidone (Risperdal Consta ${ }^{\circledR}$ ), olanzapine (Zypadhera $\left.{ }^{\circledR}\right)$, paliperidone (Xepilon $\left.®\right)$ and aripiprazole (Abilify Maintena ${ }^{\circledR}$ ) currently available.

The aim of this study was to present a case history of the patient to whom monthly injections of aripiprazole effectively prevented both relapses of psychotic symptoms and hospitalizations.

Case report: A 55-year-old male patient with a 13-year history of paranoid schizophrenia has been effectively treated with aripiprazole (LAI) ( $400 \mathrm{mg}$, every 4 weeks). During the last 8 years of treatment his mental state has been stabilized, without any acute psychotic symptoms and without any anxiety, or violent behaviours. Moreover, there have been no psychotic symptoms, or suicidal thoughts, or tendencies recordered. Therefore, no hospitalization has been required. However, despite the treatment, negative symptoms such as blunted affect, cognitive dysfunction and social withdrawal have been sustained.

Discussion: The available articles on aripiprazole (LAI) treatment indicate that it was effective in reducing the positive and negative symptoms of schizophrenia, as well as reducing the frequency and duration of hospitalization. However, the case report of a patient who has not had relapses of psychotic symptoms and suicidal thoughts and has not been hospitalized during 8 years of treatment with aripiprazole (LAI) has not yet been reported.

Conclusions: Regular, long-term injections of aripiprazole (LAI) are very effective at preventing positive symptoms of schizophrenia development and preventing both suicidal thoughts and hospitalizations. Therefore, treatment with this drug in everyday practice should be increased.
\end{abstract}

Keywords: long-acting injectable (LAI) aripiprazole; paranoid schizophrenia; Abilify Maintena®; psychosis

\section{Streszczenie}

Schizofrenia paranoidalna jest przewlekłym zaburzeniem psychotycznym w leczeniu której stosowane mogą być długodziałające leki przeciwpsychotyczne (LAI) podawane domięśniowo. Aktualnie dostępne atypowe leki przeciwpsychotyczne (LAI) to risperidon (Rispolept Consta $($ ), olanzapina (Zypadhera $($ ), paliperidon (Xeplion $($ ), oraz aripiprazol (Abilify Maintena $($ )).

Celem pracy jest przedstawienie przypadku pacjenta, u którego co miesięczne iniekcje aripiprazolu (LAI) skutecznie zapobiegały zarówno nawrotowi objawów psychotycznych jak i hospitalizacji.

Opis przypadku: Pacjent lat 55, chorujący na schizofrenię paranoidalną od 13 lat, skutecznie leczony aripiprazolem (LAI) w dawce $400 \mathrm{mg} / \mathrm{raz}$ na 4 tygodnie. W ciągu ostatnich 8 lat leczenia tym lekiem stan psychiczny pacjenta był ustabilizowany bez ostrych objawów psychotycznych z jednostajnym nastrojem, bez objawów lękowych i zachowań agresyjnych. Pacjent nie miał nigdy myśli i tendencji samobójczych oraz nawrotu objawów pozytywnych, dzięki czemu nie był ani razu hospitalizowany. Jednakże, pomimo leczenia u pacjenta utrzymywały się objawy negatywne takie jak: zubożenie afektu, zaburzenia kognitywne i wycofanie społeczne. 
Dyskusja: Dostępna literatura dotycząca leczenia aripiprazolem (LAI) wskazuje, że był on skuteczny w redukowaniu pozytywnych i negatywnych objawów schizofrenii, oraz zmniejszaniu częstości hospitalizacji i długości jej trwania. Jednakże, przypadek pacjenta, u którego w ciągu 8 lat leczenia aripiprazolem (LAI) nie stwierdzono nawrotu objawów psychotycznych, nie wystąpiły myśli samobójcze, a pacjent nie był ani razu hospitalizowany jak dotąd nie został jeszcze opisany i opublikowany. Wnioski: Regularne iniekcje aripiprazolu (LAI) są bardzo skuteczne w wieloletnim zapobieganiu nawrotom pozytywnych objawów schizofrenii, występowaniu myśli i tendencji samobójczych oraz zapobieganiu hospitalizacji. Stąd też stosowanie tego leku w codziennej praktyce klinicznej powinno być zwiększane.

Słowa kluczowe: długodziałający, domięśniowy aripiprazol (LAI); schizofrenia paranoidalna; Abilify Maintena®; psychoza

\section{Introduction}

Paranoid schizophrenia is a chronic, psychotic disorder characterised by multiple relapses of psychosis during a patients' lifetime, which may have negative consequences in terms of psychosocial functioning. Exacerbations of schizophrenic symptoms may result in decreased self-esteem and autonomy, increased risk of self-harm and violent behaviours towards others, increased risk of suicide, disruptive communication with other people and a complete lack of interests and with social withdrawal $[1,2,3]$. Therefore, preventing further relapses of the illness plays a major role in sustaining patients' daily functioning and requires compliance to antipsychotic treatment. Noncompliance with antipsychotic treatment is a common problem [3], which may be solved by using (LAI) antipsychotic medication.

There are four atypical long-acting antipsychotic drugs, (risperidone (Risperdal Consta $\AA$ ), olanzapine (Zypadhera $\AA$ ), paliperidone (Xepilon $\AA$ ) and aripiprazole (Abilify Maintena $\left({ }^{\circledR}\right)$ ) currently available $[1,4]$. Aripiprazole (LAI) is the first dopamine D2 receptor partial agonist available as (LAI)- intramuscular depot formulation of aripiprazole for the treatment of schizophrenia [5]. Aripiprazole (LAI) has shown good results at treating both positive and negative symptoms, in comparison to other (LAI) antipsychotic medication, by acting as a partial agonist of D2 receptors. This drug also binds with 5-HT1A receptors as an agonist and with 5-HT2A as an antagonist [2]. Moreover, aripiprazole (LAI) is a safer, better tolerated drug with lower potential for worsening metabolic parameters (weight gain, dyslipidaemia and hyperglycaemia) compared to other atypical (LAI) antipsychotic drugs [6], which is linked with a moderate affinity for $\alpha$-adrenergic or histaminergic receptors and the absence of an affinity for cholinergic receptors [2].

Clinical research has shown that a once-monthly injection of aripiprazole (LAI) (400 mg), to patients whose schizophrenia had responded well to oral aripiprazole, was both effective for long-term maintenance of therapeutic results (clinical trial 247 [NCT00706654], Otsuka) - up to 38 weeks, clinical trials: 246 [NCT00705783], Otsuka and 248 [NCT00731549], Otsuka - up to 52 weeks) [7,8,9] and in the acute treatment of psychosis (clinical trial 291 [NCT01663532], Otsuka) [10]. Additionally, longterm treatment with this drug had positive influence on stabilization of schizophrenia symptoms and on better psychosocial functioning. Aripiprazole (LAI) also decreases frequency of psychosis relapses and hospitalizations $[1,8]$.

Similar to our case report of a patient with paranoid schizophrenia whose treatment with aripiprazole (LAI) has been very effective at preventing psychotic symptoms, suicidal thoughts and hospitalizations has not yet been described and published.

\section{Case presentation}

A 55-year old male patient with a 13-year history of paranoid schizophrenia has been treated with aripiprazole (LAI) (400mg, once per month) for more than 8 years ( 4 years as a clinical trial patient and the last 4 years as an out-patient). It was known from his medical history that the first psychotic symptoms (auditory hallucinations, delusions of persecution, thought broadcasting) occurred 15 years ago. Pernazine (75 $\mathrm{mg} / \mathrm{d}$ ) was commenced, but non-compliance of the patient resulted in the intensification of psychotic symptoms. Triazodone $(75 \mathrm{mg} / \mathrm{d})$ was given with good results. Over the next 5 years the patient was treated as an outpatient using monotherapy with 3 drugs (haloperidol $5 \mathrm{mg} / \mathrm{d}$, risperidone $5 \mathrm{mg} / \mathrm{d}$ and olanzapine $10 \mathrm{mg} / \mathrm{d}$ ), but compliance was poor owing to negative side effects (problems with sleep, feeling of emptiness in his head, and chronic fatigue). The patient had never been treated with antidepressant or anxiolytic medication and had never taken any recreational drugs (e.g. cocaine, marihuana), or novel psychoactive substances. The patient reported not to drink alcohol, or smoke cigarettes and had no significant history of organic disease. The patient had been working until the first psychotic symptoms developed. Then, had a part-time job, but due to relapses of psychosis, required social security benefits in 2010 . He is a single man without children, who lives with his cousin's family, helping with 
the housework.

In March 2010 olanzapine (15 mg/d) was commenced because of the intensification of psychotic symptoms (auditory hallucinations, delusions of influence), which dose was titrated up to $25 \mathrm{mg} / \mathrm{d}$ after few weeks. This drug was taken by the patient until November 2011, when he was entered into a clinical trial. Olanzapine dose was decreased to $15 \mathrm{mg} / \mathrm{d}$ and aripiprazole was commenced (10 mg/d). Olanzapine was gradually withdrawn and aripiprazole dose was titrated up to $20 \mathrm{mg} / \mathrm{d}$ in January 2012. In May 2012 the patients' treatment was switched from oral aripiprazole to injections of aripiprazole (LAI) (400 mg/once per month), which the patient (as a participant of the clinical trial) continued until March 2016.

Further treatment with this drug as an out-patient (since April 2016 until now- September 2020) has been possible as the drug has been purchased for the patient by a private person. During the last 4 years (since April 2016) the mental state of the patient has been stabilized, without acute psychotic symptoms, with the treatment of aripiprazole (LAI) (400 mg/once per month). During this time his affect has been constricted or blunted (decrease in facial expression and decrease in expressive gestures and other body language), mood has been neutral and periodical slowdown of psychomotor drive has been observed. The patient has not had any suicidal thoughts and he has not attempted to commit suicide. During regular doctor visits, contact with the patient has been superficial, the patient answering with short, but logical sentences or with single words, depending on his mood. Also, a temporary lack of insight and problems with understanding of the disease by the patient have been observed. Moreover, cognitive dysfunctions of different intensity were present (problems with paying attention, distortions of abstractive thinking and generalization) and understanding of complex matters or dealing with official matters have been difficult for the patient to manage. Symptoms of social withdrawal, avoidance of people, asociality (the lack of desire to form relationships) and difficulties in communication with people were noticed. Other schizophrenia-related symptoms such as self-neglect, particularly with hygiene and self-care such as wearing inappropriate clothing for the weather, were also observed. However, anxiety symptoms or aggressive behaviours were not present. During this 4 years treatment with aripiprazole (LAI) the patient has regularly (once a month) visited for injections of the drug. The drug has been very well tolerated as no side effects have been observed. The injections are made alternately into right and left gluteal muscles and each time a place of injection is checked. This evaluation of injections' place is made in order to prevent from injection into adhesion.
There were not any ailments connected with injections except short-lasting redness of the skin and sporadic pain at the place of injection. In patient's opinion once-monthly injections of the drug are much more comfortable way of the treatment comparing to a necessity of swallowing pills every day. Also, a lack of side effects of the treatment contrary to oral treatment with tablets encourages patient to monthly visits and injections of aripiprazole (LAI)

The results of the laboratory tests conducted regularly have been within reference values and no abnormalities in electrocardiogram (ECG) have been noticed. Throughout the last 4 years of treatment with aripiprazole (LAI) no organic disorders have developed. Also, suicidal thoughts have been absent and no relapses of psychotic symptoms have been observed. Consequently, the patient has not been hospitalized at all and additional treatment with antipsychotic drugs has not been necessary.

Written consent was obtained from the patient to publish this case report.

\section{Discussion}

The literature search on case reports of patients with similar history and treatment outcome was conducted and no results have been obtained. Therefore, the case of effective and long-term (8 years) treatment with aripirazole (LAI) of a patient with paranoid schizophrenia is unique. Available results from clinical trials (246 [NCT00705783], Otsuka and 247 [NCT00706654], Otsuka) indicate that aripiprazole (LAI) (400 mg/once a month) is effective in maintenance therapy (with no acute psychotic symptoms in patients) for 52 weeks (clinical trial 246 [NCT00705783], Otsuka) [8] or for 38 weeks (clinical trial 247 [NCT00706654], Otsuka) [7]. Moreover, further treatment (another 52 weeks) of patients who were enrolled in clinical trial 248 ([NCT00731549], Otsuka) from clinical trials: 246 ([NCT00705783], Otsuka) and 247 ([NCT00706654], Otsuka), resulted in the long-term stability of symptom improvement [9]. The presented case is worth paying attention as showing the effectiveness of treatment with aripiprazole (LAI), which has been sustained much longer (for 8 years) in comparison to 38 or 52 weeks, or in the further 52 weeks as observed in clinical trials $[7,8,9]$.

Furthermore, clinical trials revealed that aripiprazole (LAI) (400 mg/per month) significantly delays the time to exacerbation of psychotic symptoms/ impending relapse, and that the rate of impending relapse was also significantly lower in comparison to placebo or $50 \mathrm{mg}$ of aripiprazole (LAI) $[2,5,8]$. The risk of relapse after remission increased during further months of treatment with this drug and was evaluated as 5.4\% after 3 months; $8.9 \%$ after 6 months and $21.2 \%$ after 9 
months, respectively [11]. Despite the increased risk of relapse of psychotic symptoms in our patient, long-term use of aripiprazole (LAI) prevented psychotic symptom development, so no relapse was observed. Hence, the patient has not been hospitalized during the last 8 years of treatment. This fact is worth noting, as other patients treated with aripiprazole (LAI) have shown a significant decrease in the mean number of hospitalizations and hospital length of stay [12], however hospitalizations were not excluded completely. Contrary to our patient, the patients who were hospitalized had suicidal thoughts (4.3\%), but none of them actually committed suicide [9] . Prevention from hospitalization and lack of psychotic symptoms and suicidal thoughts seems to be the result of improved compliance (injection of the drug every 4 weeks) and a stable concentration of the drug in the patient's blood. It has been revealed that gaps in medication compliance as brief as 1-10 days may be associated with a 2 -fold increase in hospitalization [13]. More than $67 \%$ of the patients treated with aripiprazole (LAI) experienced side effects such as insomnia (10\%-11.7\%), akathisia (9.1\%-10.6\%), headache (5.9\%-9.8\%), weight loss (9.8\%), nasopharyngitis $(7.0 \%-7.9 \%)$, injection site-pain $(7.5 \%$ $2.8 \%)$, anxiety $(6.8 \%-7.2 \%)$ and weight gain $(4.2-25.7 \%)$ $[7,8,11,14]$. However, none of these symptoms, except short-term injection site-pain, have been present in our patient which indicates a very good tolerance of the drug.

Despite the years of effective treatment with aripiprazole (LAI) at preventing both the positive symptoms of schizophrenia and hospitalization, it has been less effective at diminishing the negative symptoms of schizophrenia [15]. Symptoms such as blunted affect, cognitive dysfunction, social withdrawal, interpersonal problems and problems with self-care and hygiene have been sustained in our patient. Whereas, a clinically significant decrease of negative symptoms of schizophrenia and improvement of personal and social functioning have been observed among patients from clinical trials $[3,7,8]$.

The exact mechanism of the action of aripiprazole (LAI) has not been fully elucidated, but it is believed that as a partial agonist this drug can regulate excess dopamine activity in the mesolimbic pathway to limit positive symptoms, while allowing sufficient dopamine signaling in the mesocortical pathway, which is linked to reductions of negative and cognitive symptoms. Moreover, a moderate affinity of aripiprazole for $\alpha$-adrenergic or histaminergic receptors, and absence of affinity for cholinergic receptors guarantee its safety and tolerability profile [16].

In summary, the case presented here shows that regular injections of aripiprazole (LAI) over a few years may prevent positive symptoms of schizophrenia, prevent both suicidal thoughts and hospitalizations. Lack of side effects and a very good tolerance of the drug are premise to more common treatment.

\section{Acknowledgements}

The authors would like to thank Mr Peter KosmiderJones for proofreading the English version of the manuscript.

\section{Wstęp}

Schizofrenia paranoidalna jest przewlekłym zaburzeniem psychotycznym w przebiegu którego obserwuje się wielokrotne nasilanie objawów psychotycznych w ciągu życia, co ma negatywny wpływ na psychosocjalne funkcjonowanie pacjentów. Zaostrzenie objawów chorobowych może przyczyniać się do obniżenia poczucia własnej wartości i autonomii, zwiększać ryzyko samouszkodzeń lub zachowań agresywnych w stosunku do innych osób, indukować zachowania samobójcze, upośledzać zdolności komunikacji z innymi osobami oraz prowadzić do całkowitej utraty zainteresowań i wycofania społecznego [1,2,3]. Stąd też zapobieganie kolejnym zaostrzeniom choroby odgrywa kluczową rolę $\mathrm{w}$ podtrzymaniu funkcjonowania pacjenta, co wymaga regularnego przyjmowania leków przeciwpsychotycznych przez pacjentów. Nieregularne przyjmowanie doustnych leków przeciwpsychotycznych jest powszechnym problemem [3], dlatego też długodziałające leki przeciwpsychotyczne (LAI) podawane domięśniowo niwelują ten problem.

Aktualnie dostępnych jest kilka atypowych leków przeciwpsychotycznych $\mathrm{w}$ formie LAI, są to risperidon (Rispolept Consta ${ }^{\circ}$ ), olanzapina (Zypadhera $\left.{ }^{\circledR}\right)$, paliperidon (Xeplion $®$ ) oraz aripiprazol (Abilify Maintena $\left.{ }^{\circledR}\right)[1,4]$. Abilify Maintena ${ }^{\circledR}$ jest pierwszym, częściowym agonistą receptorów dopaminergicznych D2 $\mathrm{w}$ formie depot (LAI) stosowanym w leczeniu schizofrenii [5]. Jego agonistyczne wiązanie $\mathrm{z}$ receptorami D2 warunkuje wysoką skuteczność w leczeniu objawów pozytywnych i negatywnych schizofrenii w porównaniu $\mathrm{z}$ innymi atypowymi lekami przeciwpsychotycznymi (LAI). Lek ten wiąże się również z receptorami 5-HT1A jako agonista oraz z receptorami 5-HT2A jako antagonista [2]. Ponadto, aripiprazol (LAI) jest bezpieczniejszy, lepiej tolerowany i ma znacznie mniejszy potencjał w indukowaniu zmian $w$ parametrach metabolicznych (dyslipidemia, hyperlipidemia, wzrost masy ciała) 
w porównaniu z innymi lekami (LAI) z tej grupy [6]. Wynika to z faktu, że aripiprazol (LAI) ma umiarkowane powinowactwo do receptorów $\alpha$-adrenergicznych oraz histaminergicznych i nie wiąże się z receptorami cholinergicznymi [2].

Jak wykazały badania kliniczne aripiprazol (LAI) podawany raz w miesiącu, w dawce $400 \mathrm{mg}$ pacjentom najpierw ustabilizowanym doustnym aripiprazolem $\mathrm{w}$ tabletkach, był skuteczny zarówno jako lek podtrzymujący długotrwale efekty leczenia lekiem doustnym (badanie kliniczne 247 [NCT00706654], Otsuka) do 38-tygodnia jego stosowania, (badanie kliniczne 246 [NCT00705783], Otsuka i badanie kliniczne 248 [NCT00731549], Otsuka) do 52 tygodnia jego stosowania [7,8,9], jak i w stanach nagłego zaostrzenia objawów schizofrenii (badanie kliniczne 291 [NCT01663532], Otsuka) [10]. Co więcej, jego długotrwałe stosowanie miało korzystny wpływ na stabilizację objawów chorobowych i lepsze psychospołeczne funkcjonowanie. Aripiprazol (LAI) zmniejsza również częstość nawrotów objawów psychotycznych i hospitalizacji $[1,8]$.

Podobny do naszego przypadek pacjenta chorującego na schizofrenię paranoidalną, u którego 8-letnie leczenie aripiprazolem (LAI) było bardzo skuteczne w zapobieganiu nawrotom objawów psychotycznych, występowaniu myśli i tendencji samobójczych oraz zapobieganiu hospitalizacji, jak dotąd nie został opisany i opublikowany.

\section{Opis przypadku}

55-letni mężczyzna chorujący od 13 lat na schizofrenię paranoidalną leczony aripiprazolem (LAI) (400mg, iniekcja raz w miesiącu) od 8 lat (4 lata jako pacjent biorący udział w badaniu klinicznym i 4 lata jako pacjent z Poradni Psychiatrycznej). Z historii choroby wiadomo, że pierwsze objawy psychotyczne tj. halucynacje słuchowe, nasyłanie myśli i urojenia prześladowcze wystąpiły 15 lat temu. Włączono pernazynę $(75 \mathrm{mg} / \mathrm{d})$, którą pacjent sam odstawił (nasilenie objawów psychotycznych), dlatego włączono trazodon $(75 \mathrm{mg} / \mathrm{d}) \mathrm{z}$ dobrym skutkiem. W ciągu kolejnych 5-ciu lat pacjent był leczony ambulatoryjnie haloperidolem $(5 \mathrm{mg} / \mathrm{d})$, risperidonem $\quad(5 \mathrm{mg} / \mathrm{d}) \quad \mathrm{i}$ olanzapiną $(10 \mathrm{mg} / \mathrm{d}) \mathrm{w}$ monoterapii. Leki te pacjent odstawiał samowolnie $\mathrm{z}$ powodu objawów ubocznych (uczucie pustki w głowie, problemy ze snem, poczucie otumanienia i zmęczenia). Pacjent nigdy nie przyjmował leków przeciwdepresyjnych, ani uspokajających, nie zażywał narkotyków, ani substancji psychoaktywnych. Pacjent deklaruje, że nie pije alkoholu, nie pali papierosów i nie ma zdiagnozowanych żadnych chorób organicznych. Do czasu wystąpienia pierwszych objawów psychotycznych pacjent pracował $\mathrm{w}$ swoim zawodzie (elektromonter), później pracował dorywczo, ale ze względu na nawracające objawy psychotyczne przeszedł na rentę w 2010r. Pacjent nie jest żonaty, nie ma dzieci, mieszka z kuzynką i jej rodziną pomagając w pracach domowych.

W marcu 2010r. z powodu ponownego nasilenia objawów psychotycznych (omamy słuchowe; urojenia owładnięcia) włączono olanzapinę $(15 \mathrm{mg} / \mathrm{d})$, której dawkę po kilku tygodniach zwiększono do $25 \mathrm{mg} / \mathrm{d}$. Lek ten pacjent przyjmował do listopada 2011r. Ze względu na zakwalifikowanie pacjenta do badania klinicznego rozpoczęto zmniejszanie dawki olanzapiny do $15 \mathrm{mg} / \mathrm{d}$ oraz włączono aripiprazol (10mg/d). W styczniu 2012r. stopniowo odstawiono olanzapinę i zwiększono dawkę aripiprazolu do $20 \mathrm{mg} / \mathrm{d}$. W maju 2012r. rozpoczęto stopniowe wycofywanie aripirazolu w tabletkach i rozpoczęto podawanie aripiprazolu (LAI) (400 mg/ iniekcja raz $\mathrm{w}$ miesiącu), które $\mathrm{w}$ ramach badania klinicznego kontynuowano do marca 2016r.

Dalsze leczenie tym lekiem $w$ warunkach ambulatoryjnych (od kwietnia 2016r. aż do chwili obecnej wrzesień 2020r.) było możliwe dzięki jego zakupowi z prywatnych pieniędzy. W ciągu ostatnich 4 lat leczenia aripiprazolem (LAI) stan psychiczny pacjenta był ustabilizowany, bez ostrych objawów psychotycznych, afekt blady lub sztywny, nastrój jednostajny, bez myśli i tendencji samobójczych, okresowo spowolniały psychoruchowo z mierną aktywnością celową. Kontakt $\mathrm{z}$ pacjentem był powierzchowny, pacjent odpowiadał krótkimi, ale logicznymi zdaniami lub pojedynczymi słowami. Okresowo pacjent nie miał poczucia choroby i miał problemy z jej zrozumieniem. Co więcej, u pacjenta występowały zaburzenia kognitywne (zaburzenia myślenia abstrakcyjnego i uogólnianie) o różnym nasileniu oraz problemy ze zrozumieniem bardziej złożonych spraw. Pacjent ma problemy z nawiązywaniem relacji z ludźmi, unika ich, ma problemy z utrzymywaniem właściwej higieny osobistej oraz wyborem ubrania stosownie do pory roku. U pacjenta nie są obserwowane objawy lękowe, ani zachowania agresywne. $\mathrm{W}$ trakcie 8-letniego leczenia aripiprazolem (LAI) pacjent co miesiąc zgłasza się na wizytę $\mathrm{i}$ iniekcję, a przyjmowany lek toleruje bardzo dobrze, gdyż nie występują u niego żadne objawy uboczne. Lek w iniekcji podawany jest naprzemiennie raz w prawy raz w lewy pośladek, a miejsce podania jest każdorazowo oceniane. Ocena ta dokonywana jest zarówno przed iniekcją celem uniknięcia podania leku w zrost w mięśniu, jak i po iniekcji celem oceny ewentualnych zmian w miejscu ukłucia. Poza krótkotrwałym zaczerwieniem skóry w miejscu wkłucia igły oraz pojawiającym się sporadycznie bólem w momencie wykonywania iniekcji pacjent nie zgłasza innych dolegliwości. W ocenie pacjenta domięśniowe iniekcje leku, pomimo pewnych niedogodności, są zdecydowanie wygodniejszą formą 
leczenia niż konieczność codziennego, doustnego przyjmowania leków, a brak efektów ubocznych w odróżnieniu od leczenia tabletkami doustnymi dodatkowo motywuje go do comiesięcznych wizyt i iniekcji leku.

W badaniach laboratoryjnych wykonywanych okresowo u pacjenta nie stwierdza się parametrów poza wartościami referencyjnymi, a wyniki badań elektrokardiogramu (EKG) są w normie. W trakcie całego leczenia ambulatoryjnego (ostatnie 4 lata) u pacjenta nie rozwinęły się żadne choroby organiczne, pacjent nie przyjmuje też innych leków, nie ma myśli samobójczych i ani razu nie był hospitalizowany (nie zaobserwowano nawrotu objawów psychotycznych).

Pacjent wyraził pisemną zgodę na opublikowanie jego przypadku.

\section{Dyskusja}

Dokonano przeglądu literatury dotyczącej opisów przypadków pacjentów o podobnym wywiadzie i wyniku leczenia, nie uzyskując żadnych rezultatów. Zatem opisany w tym artykule przypadek 8-letniego, skutecznego leczenia pacjenta chorującego na schizofrenię paranoidalną aripiprazolem (LAI) jest opisem unikalnym. Dostępne w literaturze wyniki badań (badania klinincze: 246 [NCT00705783], Otsuka i 247 [NCT00706654], Otsuka) wskazują, że aripiprazol (LAI; $400 \mathrm{mg}$ /iniekcja raz w miesiącu) jest skutecznym lekiem w podtrzymywaniu efektów terapii (nie występowały ostre objawy psychotyczne u pacjentów) w porównaniu z pacjentami otrzymującymi placebo, przez kolejne 52 tygodnie (badanie kliniczne: 246 [NCT00705783], Otsuka) [8] lub 38 tygodni (badanie kliniczne 247 [NCT00706654], Otsuka) [7]. Co więcej, u pacjentów, którzy z tych badań zostali włączeni do kolejnego badania (badanie kliniczne 248 [NCT00731549], Otsuka; będącego badaniem otwartym) podawanie aripiprazolu (LAI) przez kolejne 52 tygodnie skutkowało długoterminowym podtrzymaniem pozytywnych efektów leczenia tym lekiem [9]. Przypadek naszego pacjenta jest godny uwagi, gdyż skuteczność leczenia schizofrenii lekiem aripiprazol (LAI) była utrzymana przez kilka lat (łącznie 8 lat), a nie przez 38, 52 tygodnie, lub kolejne 52 tygodnie jak to miało miejsce w badaniach klinicznych $[7,8,9]$.

Ponadto, badania kliniczne wykazały, że aripiprazol (LAI; $400 \mathrm{mg}$ ) znacząco wydłużał czas pojawienia się objawów psychotycznych lub ich nasilenia oraz, że był bardziej skuteczny w działaniu w porównaniu z placebo, czy aripiprazolem (LAI) w dawce $50 \mathrm{mg} / \mathrm{na}$ iniekcję $[2,5,8]$. Ryzyko nawrotu po okresie remisji zwiększało się w kolejnych miesiącach leczenia tym lekiem (400mg) i wynosiło: $5,4 \%$ po 3 miesiącach; $8,9 \%$ po 6 miesiącach i $21,2 \%$ po 9 miesiącach [11]. Mimo znacząco zwiększonego ryzyka nawrotu objawów psychotycznych u naszego pacjenta wynikających z kilkuletniego podawania aripiprazolu (LAI) nie zaobserwowano żadnych objawów psychotycznych mogących świadczyć o nawrocie choroby. Stąd też nasz pacjent nie był ani razu hospitalizowany w ciągu 8 lat leczenia. Fakt ten jest godny podkreślenia, gdyż u innych pacjentów leczonych tym lekiem aripiprazol (LAI) znacząco obniżał częstość hospitalizacji i skracał długość jej trwania [12], ale nie zapobiegał jej zupełnie jak to ma miejsce w przypadku naszego pacjenta. Ponadto, hospitalizowani pacjenci zgłaszali myśli samobójcze (4,3\%), chociaż żaden $\mathrm{z}$ nich nie popełnił skutecznie samobójstwa [9]. Nasz pacjent pytany podczas każdej wizyty kontrolnej o myśli i tendencje samobójcze stanowczo im zaprzeczał. Najprawdopodobniej brak nawrotów objawów psychotycznych, brak myśli samobójczych, a w efekcie brak konieczności hospitalizacji pacjenta jest wynikiem zarówno dobrej współpracy w trakcie leczenia (iniekcja leku pacjentowi co 4 tygodnie) jak i stałego stężenia leku w krwi pacjenta pomiędzy kolejnymi iniekcjami. Jak wykazano przerwy w zalecanym stosowaniu odpowiedniej dawki leku trwające od 1-10 dni mogą być powiązane z dwukrotnym wzrostem ryzyka hospitalizacji [13].

Co więcej, u ponad $67 \%$ pacjentów leczonych aripiprazolem (LAI) obserwowano efekty uboczne (AE) terapii najczęściej pod postacią zaburzeń snu (10\%$11,7 \%)$, akatyzji (9,1\%-10,6\%), bólu głowy (5,9\%-9,8\%), spadku masy ciała $(9,8 \%)$, zapalenia błony śluzowej nosa i gardła (7,0\%-7,9\%), bólu w miejscu wstrzyknięcia leku (7,5\%-2,8\%), zaburzeń lękowych (6,8\%-7,2\%) i wzrostu masy ciała $(4,2-25,7 \%)[7,8,11,14]$. Objawów tych, z wyjątkiem krótkotrwałego bólu w miejscu wstrzyknięcia leku nie stwierdzono u naszego pacjenta w trakcie całego okresu leczenia, co świadczy o bardzo dobrej tolerancji leku.

O ile kilkuletnie stosowanie aripiprazolu (LAI) u naszego pacjenta było skuteczne $\mathrm{w}$ zapobieganiu wystąpienia objawów pozytywnych schizofrenii i zapobieganiu hospitalizacji, o tyle istotnie nie redukowało objawów negatywnych schizofrenii [15]. U naszego pacjenta nadal utrzymywały się objawy takie jak: zubożały afekt, zaburzenia kognitywne, wycofanie społeczne, problemy interpersonalne oraz problemy związane z dbałością o siebie, w szczególności z dbałością o higienę osobistą. Natomiast, istotne klinicznie zmniejszenie nasilenia objawów negatywnych i poprawę osobistego i społecznego funkcjonowania zaobserwowano w badaniach klinicznych $[3,7,8]$.

Pomimo, że dokładny mechanizm działania aripiprazolu (LAI) nie jest do końca poznany, uważa się, że wiązanie się tego leku jako częściowy agonista receptorów dopaminergicznych reguluje aktywność dopaminy w szlakach mezolimbicznych, co odpowiada 
za zmniejszanie objawów pozytywnych schizofrenii. Natomiast, dzięki regulowaniu przewodnictwa dopaminergicznego w szlakach mezokortykalnych wpływa na zmniejszanie zarówno objawów negatywnych schizofrenii jak i zaburzeń kognitywnych. Co więcej, umiarkowane powinowactwo aripiprazolu (LAI) do receptorów $\alpha$-adrenergicznych i histaminergicznych oraz brak powinowactwa do receptorów cholinergicznych warunkuje jego bezpieczeństwo i wysoki poziom tolerancji [16].

\section{Wnioski}

Prezentowany przypadek pacjenta pokazuje, że kilkuletnie, regularne iniekcje aripiprazolu (LAI) są bardzo skuteczne w wieloletnim zapobieganiu nawrotom pozytywnych objawów schizofrenii, występowaniu myśli i tendencji samobójczych oraz zapobieganiu hospitalizacji. Bardzo dobra tolerancja leku i brak efektów ubocznych jego stosowania stanowią mocną przesłankę do jego coraz powszechniejszego stosowania.

\section{Podziękowania}

Autorzy składają serdecznie podziękowania Panu Peter Kosmider-Jones za korektę angielskiej wersji manuskryptu.

\section{Conflict of interest}

The authors have declared no conflict of interest.

\section{References:}

1. Fagiolinia A, Agugliab E, Ballerinic A, Callistad G, Carpinielloe $B$, Clerici $M$, et al. Real-world effectiveness of long acting aripiprazole: Treatment persistence and its correlates in the Italian clinical practice. Psychiatry Res 2019; 272: 698-706.

2. Madera JJ, Such P, Zhao C, Baker RA. Symptomatic stability with aripiprazole once-monthly: efficacy analyses from acute and long-term studies. Neuropsych Dis and Treat 2019; 15: 15931604.

3. Peters-Strickland T, Baker RA, Such P, Zhang P, Madera JJ. The effect of aripiprazole once-monthly on personal and social functioning: post hoc analyses of acute and long-term studies. Neuropsych Dis and Treat 2019; 15:1659-1669.

4. Jarema M, Wichniak A, Dudek D, Samochowiec J, Bieńkowski P, Rybakowski J. Wskazówki do stosowania leków przeciwpsychotycznych II generacji o przedłużonym działaniu. Psychiatr Pol 2015; 49: 225-241.

5. Shirley M, Perry CM. Aripiprazole (Abilify Maintena $®$ ): a review of its use as maintenance treatment for adult patients with schizophrenia. Drugs 2014; 74 :1097-1100.

6. Theodoros T, Taylor M, Chu-Han Huang H, Wang N, Montamari B. Going the distance: reviewing antipsychotic depot or long-acting injectable treatments in Australasia. Australas
Psychiatry 2018; 26: 303-306.

7. Fleischhacker WW, Sanchez R, Perry PP, Jin N, Peters-Strickland $\mathrm{T}$, Johnson BR et al. Aripiprazole once-monthly for treatment of schizophrenia: double-blind, randomised, non-inferiority study. Br J Psychiatry 2014; 205: 135-144.

8. Kane JM, Sanchez R, Perry PP, Jin N, Johnson BR, Forbes RA et al. Aripiprazole intramuscular depot as maintenance treatment in patients with schizophrenia: a 52-week, multicenter, randomized, double-blind, placebo-controlled study. J Clin Psychiatry 2012; 73: 617-624.

9. Peters-Strickland T, Baker RA, McQuade RD, Jin N, Eramo A Perry $\mathrm{P}$ et al. Aripiprazole once-monthly $400 \mathrm{mg}$ for long-term maintenance treatment of schizophrenia: a 52-week open-label study. N P J Schizophr 2015; 4: 15039.

10. Kane JM, Peters-Strickland T, Baker RA, Hertel P, Eramo A, Jin $\mathrm{N}$ et al. Aripiprazole once-monthly in the acute treatment of schizophrenia: findings from a 12-week, randomized, doubleblind, placebo-controlled study. J Clin Psychiatry 2014; 75: 1254-1260.

11. Mustafa S, Bougie J, Miguelez M, Clerzius G, Rampakakis E, Proulx J et al. Real-life assessment of aripiprazole monthly (Abilify Maintena) in schizophrenia: a Canadian naturalistic non-interventional prospective cohort study. BMC Psychiatry 2019; 19: 114-123.

12. Kane JM, Sanchez R, Zhao J, Duca AR, Johnson BR, McQuade RD et al. Hospitalisation rates in patients switched from oral antipsychotics to aripirazole once-monthly for the management of schizophrenia. J Med Econ 2013; 16: 917-925.

13. Weiden PJ, Kozma C, Grogg A, Locklear J. Partial compliance and risk of rehospitalization among California Medicaid patients with schizophrenia. Psychiatric Serv 2004; 55: 886-91.

14. Mallikaarjun S, Kane JM, Bricmont P, McQuade R, Carson W, Sanchez R et al. Pharmacokinetics, tolerability and safety of aripiprazole once-monthly in adult schizophrenia: an openlabel, parallel-arm, multiple-dose study. Schizophr Res 2013; 150: 281-8.

15. Szulc A, Samochowiec J, Gałecki P, Wojnar M, Heitzman J, Dudek D. Recommendations for the treatment of schizophrenia with negative symptoms. Standards of pharmacotherapy by the Polish Psychiatric Association (Polskie Towarzystwo Psychiatryczne), part 1. Psychiatr Pol 2019; 53: 497-524.

16. Lieberman JA. Dopamine partial agonists: a new class of antipsychotics. CNS Drugs 2004; 18: 251-267.

\section{Corresponding author}

\section{Anna Szota}

Department of Psychiatry, Collegium Medicum in Bydgoszcz; Nicolaus Copernicus University in Torun, Poland,

Tel +48525854260

Fax +48525853766

e-mail: julias@vp.pl

Otrzymano:30.10.2020

Zrecenzowano:10.11.2020

Przyjęto do druku: 18.11.2020 